\title{
APRESENTAÇÁO
}

\section{MITOS DE ORIGEM NA HISTÓRIA DAS IDEIAS LINGUÍSTICAS \\ OU DO CORTE EPISTEMOLÓGICO}

(...) uma ciência não é o produto de um único homem. Galileu é o efeito, e não a causa, do corte epistemológico que se designa pelo termo "galileísmo". (PÊCHEUX E BALIBAR, Définitions, 1969, p. 11)

O que Pêcheux e Balibar afirmam sobre o nome de Galileu e o "galileísmo" para a Física pode ser pensado em relação aos nomes de Saussure ou de Chomsky para a Linguística. Os efeitos de ruptura tomados como a sua causa fazem com que a história da Linguística seja percorrida como gestos de autores, e náo na conjuntura que os possibilita ou os promove. Inspirado no texto Définitions, introdução de Pêcheux e Balibar ao livro Sur l'histoire des sciences ${ }^{1}$ (PÊCHEUX E FICHANT, 1969), o tema deste número da Fragmentum propóe pensar, a partir de uma tomada de posição materialista, os tantos começos nos estudos da linguagem.

Nas definiçôes propostas por Pêcheux e Balibar, a ideia de começo é fundamental. Analisando a Física, os autores consideram o corte epistemológico como o ponto de não-retorno a partir do qual a ciência começa. Falar de começo, e não de origem, significa que o corte constitutivo de uma ciência se efetua

necessariamente em uma conjuntura definida, na qual as origens (as filosofias e as ideologias teóricas que definem o espaço de problemas) sofrem um deslocamento na direção de um novo espaço de problemas (PÊCHEUX E BALIBAR, 1969, p. 9).

${ }^{1}$ BALIBAR, Étienne; PÊCHEUX, Michel. Définitions. In: FICHANT, Michel; PÊCHEUX, Michel. Sur l'histoire des science. Paris: François Máspero, 1969. 
$\mathrm{Na}$ formação da conjuntura na qual se produzirá o corte epistemológico, intervêm, segundo modalidades historicamente reguladas: as relaçôes de produção e o processo de produção econômico, a superestrutura jurídico-política da sociedade e as ideologias práticas (tal como definidas por Althusser), como a moral e a religião: "é a condensação desses elementos que determina as condiçóes históricas do corte" (PÊCHEUX E BALIBAR, 1969, p. 10).

Nesse processo de formação, acontecem demarcações, aperfeiçoamentos, correçóes, críticas, negaçóes de filosofias ou ideologias anteriores. Por isso, é preciso levar em conta alguns efeitos que identificam o corte epistemológico: tornar impossíveis certos discursos ideológicos ou filosóficos que o precedem; operar validaçóes, invalidaçóes ou segregaçóes nas filosofias implicadas na conjuntura em que tem lugar; determinar uma autonomia relativa da nova ciência que corresponde a ele.

Os artigos que compóem este número partem de uma posiçáo materialista na compreensão da História das Ideias Linguísticas. Eles trazem como objetos de reflexão gestos anteriores à Linguística, gestos que contribuem para a sua a legitimaçáo como ciência ou disciplina, o entremeio que a interroga (a $\mathrm{AD})$, os modos de apreensão dos seus objetos: a língua e a linguagem. Eles nos permitem pensar a conjuntura de autores, conceitos, noçôes e trabalhar sua relação com o processo de formação dos cortes epistemológicos e com os efeitos desses cortes, mas também com as contradiçôes que tornam complexa a análise das conjunturas dos Estudos da Linguagem e da Linguística.

História das Ideias Linguisticas e Análise do Discurso: o corte epistemológico parte da observação feita por Pêcheux sobre a particularidade da Linguística enquanto Ciência Humana: ela define um objeto próprio, mas não necessariamente dá continuidade ao espaço de problemas que vem com a definição do objeto. Refletindo sobre a concepção de história e de ciência na Análise do Discurso e na História das Ideias Linguísticas, Baldini, Ribeiro e Ribeiro apontam sua não-homogeneidade entre diferentes autores, tomam posição entre os autores discutidos e propóem questóes para compreender o "efeito-Saussure" na linguística contemporânea.

Toda História Começa in media res: Nietzsche e as Ciências da Linguagem interroga a presença de Nietzsche nas ciências da linguagem. "Sob que condiçôes pode Nietzsche ser filiado à História das Ideias Linguísticas? O que condiciona a possibilidade da presença de Nietzsche neste domínio? Que condiçóes possibilita Nietzsche na Linguística?”. Essas perguntas 
permitem a Machado percorrer o pensamento de Sapir e Pêcheux, entre outros, e questionar o lugar do acaso na História das Ideias.

Entre a palavra divina de São Tomás de Aquino e a palavra humana de Wilhem von Humboldt há aproximaçóes históricas possíveis? Em Os Pilares da Cristandade: Historiografia do Conceito de Palavra de Tomás de Aquino a Wilhelm von Humboldt, Tossin percorre os dois autores e pontua diferenças e semelhanças entre a palavra como categoria de explicação da linguagem humana e como representação da voz divina.

As revistas científicas têm papel fundamental, particularmente a partir do século XX, na constituição e legitimação das ciências. Em As Revistas Cientificas e a Disciplinarização dos Estudos Linguisticos no Brasil, Schneiders analisa a Revista Brasileira de Filologia, que circulou entre 1955 e 1961 no país. A autora mostra que, mesmo trazendo a Filologia como domínio de conhecimento indicado no nome, esta publicação é fundamental para a circulação de saberes produzidos no interior da Linguística.

A presença da língua portuguesa do Brasil como objeto de ensino na universidade alemã é objeto da reflexão de $A$ Brasilianistica como um Campo de Estudos Alemão sobre o Brasil e sua Lingua. Stahlhauer analisa o modo como vão se constituindo no espaço de formação universitária alemã saberes sobre a língua e, por meio dela, sobre o país e sobre o sujeito brasileiro, especialmente na relação entre as disciplinas Brasilianística e Lusitanística.

Júlio Ribeiro, Autor Fundador? busca compreender como se constrói a imagem de Júlio Ribeiro como um autor fundador na história dos estudos gramaticais e linguísticos no Brasil. Aquino questiona os critérios que são empregados para identificar o autor da Grammatica Portugueza (1881) como ponto de origem na gramatizaçáo do português e na constituição das ideias linguísticas no país.

Em Nossas Linguas São Crioulas Ou "A” Lingua Não Há: Mito? Verdade? Ou Interpretação?, Castello Branco reflete sobre as relaçóes entre línguas no Cabo Verde e problematiza o conceito sociolinguístico de lingua crioula enquanto atualização da memória do mito da língua de origem, pura, que silencia relaçấo conflitual entre unidade/diversidade.

Sobre a Noção de Práticas Linguageiras: Lugares de Emergência, Filiações e Fronteiras propóe um olhar sobre as linhas de demarcação das práticas linguageiras, tomadas na relação entre objeto real e objeto de conhecimento em diferentes autores. Se a linguagem é uma prática, como os estudos da linguagem têm compreendido essa prática? É o que o artigo de Rasia nos ajuda a pensar, mostrando as diferenças na caracterização das práticas 
linguageiras em perspectivas linguísticas que levam em conta a tomada da palavra pelos sujeitos.

A tese Lógica e Formalização na Semântica de Ducrot: Um Estudo em História das Ideias Linguisticas foi defendida em 2018 no Instituto de Estudos da Linguagem da Unicamp. Massad Castro se dedica a uma ideia - a de formalização - que tem parte decisiva nas dissensóes epistemológicas no interior da Linguística e da reflexão sobre a linguagem. Essa ideia é observada na tese em um artigo alterado e republicado em dois momentos por Oswald Ducrot, no qual o autor assume uma posição acerca da relação entre Linguística e Lógica fundamental para a constituição das bases de sua Semântica linguística. Agradecemos a Soeli Schreiber da Silva, docente da Universidade Federal de São Carlos, pelo resumo da tese.

Agradecemos às autoras e autores que aceitaram o desafio de pensar as ideias linguísticas a partir de um gesto de leitura do texto de Pêcheux e Balibar e contribuíram para a reflexão histórica sobre os começos da Linguística e da reflexão sobre a linguagem.

Sheila Elias de Oliveira (UNICAMP) Claudia Freitas Reis (IFSP - Campus Araraquara)

DOI: $10.5902 / 2179219436971$ 